\title{
Lazaroa
}

ISSN: 0210-9778

\section{Ethnobotanical study of medicinal plants from El-Jadida City (Morocco)}

\author{
Hanae Briguiche ${ }^{1} \&$ Lahcen Zidane $^{1}$
}

Received: 19 December 2015 / Accepted: 18 July 2016

\begin{abstract}
In the framework of the ethnobotanical studies on medicinal plants undertaken by the Laboratory of Biodiversity and Natural Resources of the Faculty of Sciences of Kenitra (Morocco), we are interested in the area of El-Jadida which presents a rather important floristic wealth due to the variations of the ecological conditions. By using 204 questionnaires, the ethnobotanical surveys were conducted in the field during the years 2012-2013. The location of the different sampling sites was determined by the stratified sampling method. The analysis of the results obtained from the questionnaires allowed us to identify 70 species belonging 69 genera and 37 families, the most important by its number of species are: Lamiaceae, Apiaceae, Asteraceae, Zingiberaceae, Fabaceae and Myrtaceae. The species Origanum compactum is the most used by the population of the city of El-Jadida. The relations existing between the medicinal species and types of diseases treated, has shown that most of these species are used primarily in the care of the digestive system and respiratory system. These plants are handled mainly by seed which is the plant organ most used and the decoction which is the method of preparation the most dominant among the local population.
\end{abstract}

Keywords: El-Jadida (Morocco); Ethnobotany; medicinal plants; therapeutic; questionnaire.

\section{[es] Estudio etnobotánico de las plantas medicinales de la ciudad de El-Jadida (Marruecos)}

Resumen. En el marco de los estudios etnobotánicos sobre plantas medicinales realizadas por el Laboratorio de Biodiversidad y Recursos Naturales de la Facultad de Ciencias de Kenitra (Marruecos), estamos interesados en el área de El-Jadida, que tiene una riqueza florística grande debido a los cambios significativos en las condiciones ecológicas. Se realizaron 204 encuestas etnobotánicas durante los años 2012-2013. La ubicación de los sitios de muestreo se determinó mediante un muestreo estratificado. El análisis de los resultados obtenidos de los cuestionarios nos permitió identificar 70 especies pertenecientes 69 géneros y 37 familias; las más importantes por su número de especies son: Lamiaceae, Apiaceae, Asteraceae, Zingiberaceae, Fabaceae y Myrtaceae. Origanum compactum es la especie más utilizada por la población de la ciudad de El-Jadida. La relación existente entre las especies medicinales y las enfermedades tratadas ha demostrado que la mayoría de estas especies se utilizan sobre todo en el cuidado del sistema digestivo y el sistema respiratorio. El órgano de la planta más utilizado es la semilla y la decocción es el método de preparación más habitual entre la población local.

Palabras clave: El-Jadida (Marruecos); Etnobotánica; plantas medicinales; terapéuticas, cuestionario.

\section{Introduction}

Medicinal plants have always been used in traditional medicine for thousands of years. In recent decades, there has been a growing interest in the study of medicinal plants and their traditional use in different regions of the world (Muthu \& al., 2006).The World Health Organization (WHO) defines traditional medici- ne as the set of knowledge, skills and practices based on the theories, beliefs and experiences that different cultures have used to maintain health and to prevent, diagnose, relieve or treat physical and mental illnesses (WHO, 1978).

Africa has a large variety of medicinal plants (Dibong \& al., 2011) and these are valuable resources for the vast majority of rural populations in Africa since over $80 \%$ of

\footnotetext{
1 Laboratory of Natural Resources and Biodiversity, Department of Biology, Faculty of Science, Ibn Tofail University. BP 133, 14000 Kenitra, Morocco. E-mail: Briguiche.hanae@gmail.com
} 
its populations is using them to ensure health care (Jiofack \& al., 2010).

Morocco, by its geographical location between two seas and a desert, crossed by three mountainous chains, resulting in a full range of Mediterranean bioclimates allowing the installation of a flora rich and varied with a very marked endemism factor. On the 7000 species and subspecies, 800 are aromatic and/or medicinal plants (Benabid, 2000). It is one of the Mediterranean countries that has a long medical tradition and traditional knowledge-based on medicinal plants (Scherrer \& al., 2005).

Moreover, a strong ethnomedicinal tradition is still alive in all regions of Morocco and no one suspected the richness of ethnomedicinal knowledge accumulated over centuries and which increasingly may no longer be transmitted since no serious backup is undertaken (Salhi \& al., 2010). This ethnobotanical survey proves to be essential for the knowledge of the medicinal plants and their uses. In this context, an ethnobotanical survey was carried out in the town of El-Jadida to contribute to the knowledge of those medicinal plants used in the treatment of various diseases, and to establish the list of plants that bring us the maximum information about therapeutic uses practiced by the local population in the region.

\section{Material and Methods}

\section{Study area}

El-Jadida, capital of the province of Doukkala is located at the center of Morocco, according to the following geographic coordinates: latitude of $33^{\circ} 14^{\prime} \mathrm{N}$ and longitudes of $8^{\circ} 30^{\prime} \mathrm{W}$. It extends on a surface from $6000 \mathrm{~km}^{2}$, that is to say approximately $0.85 \%$ of the total surface area of the Kingdom, which is which is bounded to the North by the Atlantic Ocean, in the east by the rural district Haouzia, in the south by the commune Oulad Hseine, and in the west by the rural district Moulay abdallah (PDC, 2011).

According to GCPH, the total population of the urban district of El-Jadida increased from 119083 in 1994 to 143419 in 2004, with an average annual growth rate of $1.93 \%$. On the geological level, El-Jadida belongs to the region of the Sahel Doukkala and it is part of a large structural unit, the western Moroccan Meseta (plateau). The Meseta field has a Mesozoic and Cenozoic age coverage which is sub-horizontal, thin and incomplete (Gigout,
Figure 1. Administrative division of El-Jadida (the six studied municipalities).

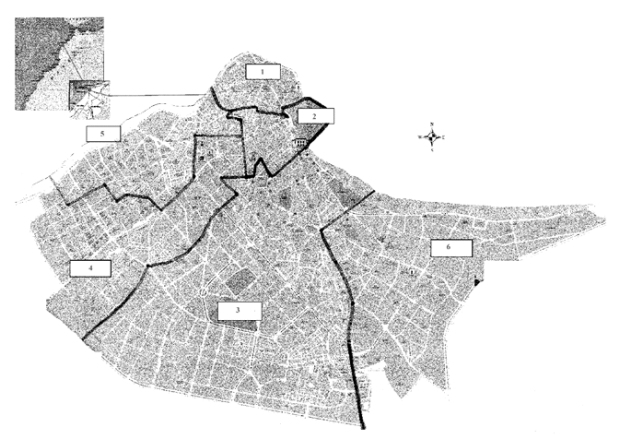

1951). According to the French classification of soils (CPCS, 1967) the soils found in the study area are included into six classes: isohumic soils, vertisols, calcimagnesic soils, slightly developed soils, iron sesquioxides soils and hydromorphic soils (Badraoui \& al., 1993).

According to the classification of climates in Morocco (Emberger, 1954), El-Jadida area is in the lower bioclimatic semi arid stage. The climate is Mediterranean, the average annual rainfall is $322 \mathrm{~mm}$, with a rainy mild winters and hot, dry summers and one average annual temperature is $18.6^{\circ} \mathrm{C}$ (ORMVAD, 2009). Agriculture in the region is based mainly on gardening and cereal. Livestock is also an important activity for the population, next to agriculture, it is considered an essential complement to the economic development and it is based mainly on sheep and cattle (DPA, 2007).

\section{Data collection}

The population of El-Jadida was investigated during the years 2012/2013 through a stratified random sampling (Benkhnigue \& al., 2010). In this work, sampling was divided into 6 layers which correspond to the number of districts of El-Jadida city (Figure 1). Small numbers samples (34 people) are then formed for each of the six strata and they are put together to form the aggregate sample (204 people).

Then the research based on direct and individual questions with traditional therapists available who agreed to answer our questions using a predetermined questionnaire with specific questions about the informant (age, sex, therapeutic practice,...) and medicinal plants used by this one (vernacular name, type of disease being treated, used part, method of preparation...) (Appendix1). We can get the maximum information about the use of medicinal plants by the local population. 


\section{Species identification}

In the laboratory of Biodiversity and Natural Resources Faculty of Kenitra, and using the Flora, the catalogue and various books of medicinal plants, we determined species collected during the floristic surveys, in order to draw up a complete list of species medicinal identified in the study area. (Appendix 2).

\section{Results and Discussion}

\section{Floristic Aspect}

Analysis of the collected information show that of the 70 species found in the study area fourteen are relatively more used than the other species in traditional phytotherapy by the local population (Figure 2). Origanum compactum is the most popularly used (47 quotations). It is an Ibero-Moroccan endemic species (Jahandiez \& Maire, 1931-1932-1934, Emberger \& Maire, 1941) and our results prove that this plant is used in traditional herbal medicine by the local population. It is common in northern and central Morocco and it is harvested in the country and sold in markets among herbalists.

Figure 2. Number of cites for the most used medicinal species in El-Jadida.

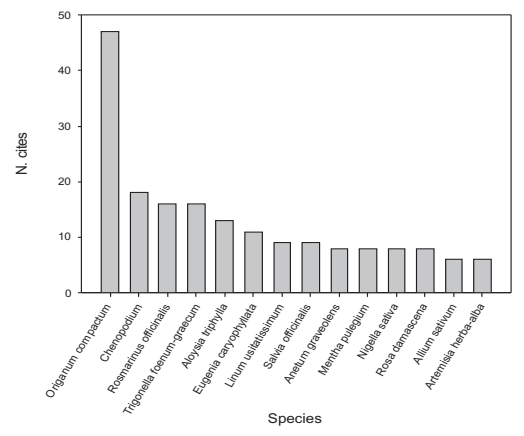

Figure 3. Most used species according to the botanical families in El-Jadida.

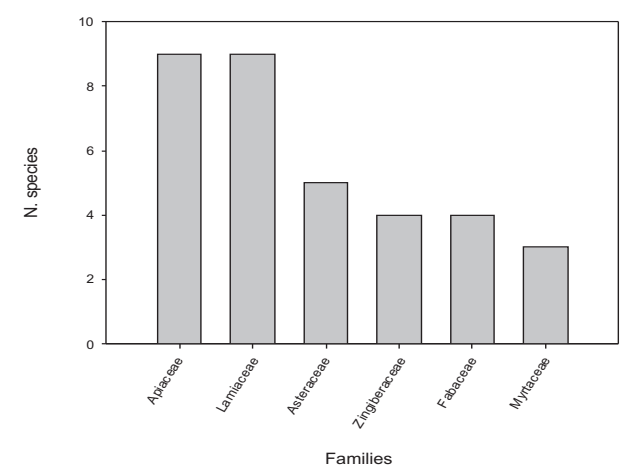

Figure 4. Percentages of parts used by the population in El-Jadida.

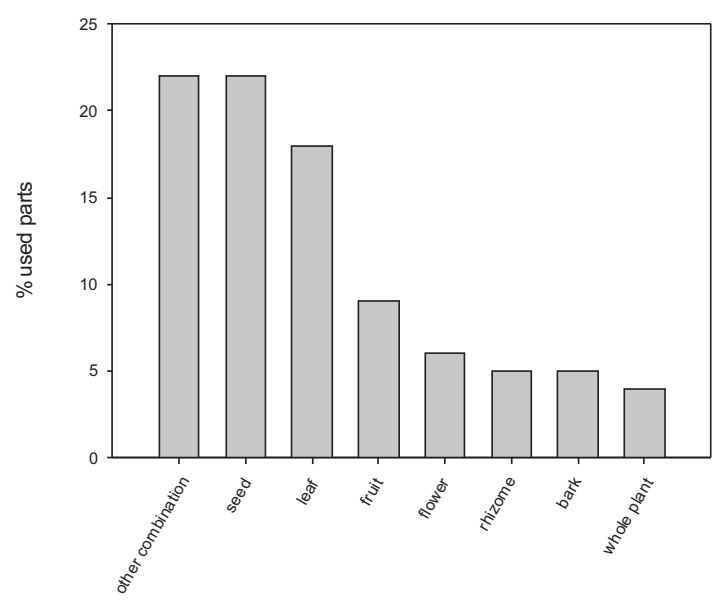

Figure 5. Percentages of preparation methods used by the population in El-Jadida.

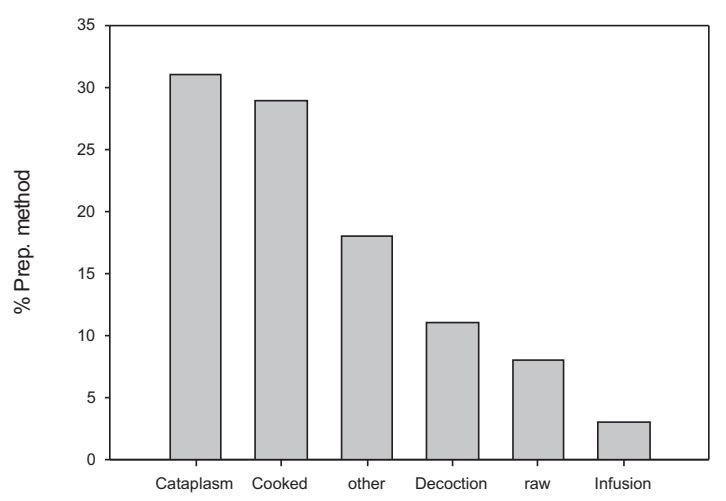

The results showed that from the 70 species reported they are included in 69 genera and 37 families botanical (Appendix 2). Similarly, the number of Moroccan medicinal plants do not exceed 600 species (Rejdali \& al., 2002) being $11.66 \%$ of the total Moroccan flora, which reflects in a very clear way the great wealth of medicinal herbs of this region. Among the 37 encountered families, Apiaceae and Lamiaceae ranks first with 9 species each one $(12.85 \%)$ in the medicinal flora of El-Jadida. Asteraceae is the second family with 5 species $(7.14 \%)$, then the Zingiberaceae and Fabaceae with 4 species each one $(5,71 \%)$, and finally the Myrtaceae with 3 species $(4.29 \%$; Figure 3 ).

\section{Ethnobotanical Aspect}

The results have been also discussed comparing the resence of plants according to their frequency of use and the types of diseases treated. 
Parts used: The ethnobotanical survey revealed that the seeds and other combinations are the most part used in this region with the same percentage $(22 \%)$, come next, the leaves with percentage of $(18 \%)$, stems and fruits with $(18 \%)$, flowers $(6 \%)$, rhizomes and the bark $(10 \%)$. The rest of the used partsis represented with a percentage $4 \%$ (Figure 4 ).

This high frequency of use of the leaves, seeds and fruit (49\%) can be explained by the ease and speed of harvesting (Bistindou, 1986).

The mode of preparation: In order to facilitate the administration of the active ingredient, several modes of preparations are employed namely: the decoction, the infusion, the fumigation, the cataplasm. The decoction is the preparation method which is the most used by the majority of the diseases (colds, asthma, ulcers...) identified in the area, with a percentage respectively of $31 \%$ (Figure 5). Then come,other modes of preparation, such as the use for raw with a percentage of $29 \%$, the infusion with a percentage of $18 \%$, then in the form of cataplasm with a percentage of use of $11 \%$. Other preparation methods namely cooked and others $11 \%$. The high percentage of the preparation in decoction shows that the local population believes in this type of preparation and finds it adequate to heat the body and to disinfect the plant. In addition, the decoction makes it possible to collect the most active ingredients and reduces or cancels the toxic effect of certain receipts (Salhi \& al., 2010).

Figure 6. Percentage of plants used according to the treated affections.

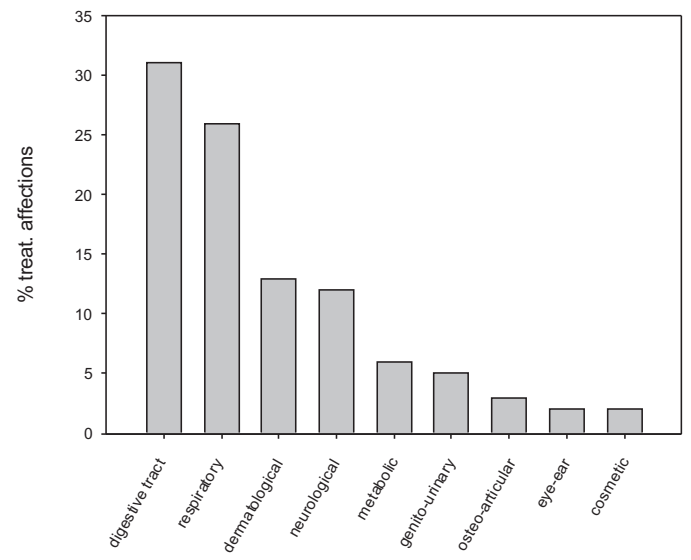

The treated diseases: The existing relations between the medicinal plants and different diseases treated showed how those related with the digestive systems (31\%) included the majority of the medicinal herbs studied. Similar results were found by Husein Souâda (Huseini \& al., 2011). They were followed by the treatment of respiratory system affections $(26 \%)$, genitourinary affections $(13 \%)$, neurological affections $(12 \%)$ and the rest of other diseases (18\%, Figure 6).

\section{Conclusions and Recommendations}

This study has allowed us to highlight the important role of traditional herbal medicine in order to achieve the most reliable possible inventory of medicinal plants which are used in the city of El-Jadida and gather information about the practical therapeutic uses in this city. The floristic analysis made it possible to identify 70 species belonging to 37 families botanical, with a predominance of two families such as Lamiaceae and Apiaceae with 9 each one species $(12.85 \%)$. From an ethnobotanical and pharmacological point of view the seed is the part most commonly used $(22 \%)$ and the decoction is the galenical form the most practised (31\%). Similarly, on the whole treated diseases, the digestive disorders are the most mentioned diseases with a percentage of $31 \%$. Finally, it is clear from these conducted ethnobotanical researches that the traditional use of medicinal plants is still popular in this region despite the medical technology revolution.

We would like to make the following recommendations:

Conservation of the threatened medicinal plants by using modern techniques.

These medicinal plants should be used as income generating source and to improve the socio-economic condition of the inhabitants.

Local people should be aware on the importance of medicinal plants.

People should be trained for collection, drying and processing of medicinal plants.

Integrate the medicinal plants in the economy and the health care system into Morocco.

The Information into ethnobotanical can be recycled by various manners, for example through open workshops for general public.

\section{Acknowledgements}

We would like to thank the anonymous reviewers for his valuable remarks that have improved the quality of this work. 


\section{References}

Badraoui, M., Bouaziz, A. \& Kabbassi, M. 1993. Physical constraints and potentials of the soil environment in Doukkala. Project: Development and improvement of grain production irrigated. Vol. 1 (2). IAV Hassan II, Rabat.

Bammi, J. \& Douira, A. 2002. Medicinal plants in the forest of Achach (central plateau, Morocco). J. Acta Bot. Mal. 27: 131-145.

Benabid, A, 2000. Flora and ecosystems of Morocco, Evaluation and safeguarding of the biodiversity. Ibis Press, Paris, 360pp.

Benkhnigue, O., Zidane, L., Fadli, M., Elyacoubi, H., Rochdi, A. \& Douira, A. 2010. Ethnobotany of medicinal plants in the region of Bel Mechraa Ksiri (the Gharb region of Morocco). J. Acta Bot. Barc. 53: 191-216.

Bitsindou, M., 1986. Investigations into traditional phytotherapy in Kindamba and Odzala (Congo) and analyzes convergences of use of the medicinal herbs in central Africa. Mem. Doc. (ined.). Univ. Libre Bruxelles. 482 pp.

CPCS. 1967. Soil Science Commission and soil mapping, soil classification, Geology and Soil Science Laboratory. Nat. Sch. Agron., Moody. 87pp.

Dibong, S.D., Mpondo, M.E., Nigoye, A., Kwin, M.F. \& Betti, J.L. 2011. Ethnobotany and phytomedicine medicinal plants of Douala, Cameroon. [Ethnobotany and phytomedicine of medicinal plants sold in Douala markets]. J. Appl. Biosci. 37: 2496-2507.

Emberger, L. \& Maire, R. 1941. Catalogue of plants of Morocco (Spermatophytes and Pteridophytes). Tome IV, Supplement to volumes I, II, and III. Pp. 915-1181. Minerva, Algiers.

Emberger, L. 1954. Biogeographic classification of climates. Work Research of Laboratory. Geology. Zoology, Univ.Montpellier. Bot.7 Series: 3-43.

Hseini, S., Kahouadji, A., Lahsissène, H.\& Tijane, M. 2007. Floristic and ethnobotanical analyzes of vascular medicinal plants used in the region of Rabat (Western Morocco). Lazaroa 28: 93-100.

GCPH. 204. General Census of Population and Housing.

Gigout, M. 1951. Geological Study of the Meseta, western Morocco (hinterland of Casablanca, Safi and Mazagan). Trav. Inst. Sci., 2 Vol.,Chérifien. Morocco. 507pp.

Jahandiez, E. \& Maire, R. 1931. Catalogue of plants of Morocco (spermatocytes and Pteridophytes). Volume One. Pteridophytes, Gymnosperms, and Monocotyledons. Minerva, Alger. $150 \mathrm{pp}$.

Jahandiez, E. \& Maire, R. 1932. Catalogue of plants in Morocco. Volume second: Dicotyledons Archichlamydées. Pp. 161-558. Minerva, Alger.

Jahandiez, E. \& Maire, R. 1934. Catalogue of plants in Morocco. Third volume: Dicotyledons gamopetalous and additional volumes I and II. Pp. 559-913. Minerva, Alger.

Jiofack, T., Fokunang, C., Guedje, N., Kemeuze, V., Fongnzossie, E., Nkongmeneck, B.A., Mapongmetsem, P.M. \& Tsabang N. 2010. Ethnobotanical uses of plants of medicinals ethnoecological two regions of Cameroon. Int. J. Med. Med. Sci. 2 (3): 60-79.

Muthu, C., Ayyanar, M., Raja, N. \& Ignacimuthu, S. 2006. Medicinal plants used by traditional healers in Kancheepuram district of Tamil Nadu, India. J. Ethnobiol. Ethnomed. 2: 43.

ORMVAD. 2009. Regional Office of Agricultural Development of Doukkala, Morocco.

PDA. 2007. Provincial Directorate of Agriculture of El-Jadida. Min. Agric. Rur. Dev. Fish., Morocco.

PDC. 2011. Municipal Development Plan. Min. Int., Urban district El-Jadida, El-Jadida.

Rejdali, M. 1996. The flora of Morocco: current status and conservation perspectives. Valuation of biodiversity and medicinal plants. Acts. Pp. 17-22. Ed. Rabat.

Scherrer, A.M., Motti, R. \& Weckerle, C. 2005. Traditional plant use in the areas of Monte Vesole and Ascea, Cilento National Park (Campania, Southern Italy). J. Ethnopharmacol. 97: 129-143.

Salhi, S., Fadli, M., Zidane, L.\& Douira, A. 2010. Floristic and ethnobotanical studies of medicinal plants in the city of Kenitra (Morocco). Lazaroa 31: 133-146.

WHO. 1978. World Health Organization, Promotion and development of traditional medicine. Ser. Tec. Rep. n. 622. Geneva, Switzerland. 43pp. 
Appendix 1. Survey. Medicinal and herbal plants

Date:

Region:

Commune:

Author:

Place:

Informant:

Age:

Profession:

family situation: Single $\square$ Married $\square$

Gender: Male $\square$ Female $\square$

Education Level: primary $\square$ secondary $\square$ university $\square$

Locality : Douar $\square$ village $\square$ city $\square$ nomad $\square$

\section{Therapeutic practices:}

When you feel sick, you address:

A traditional medicine $\square$, why: effective $\square$ cheapest $\square$

Acquisition $\square$ drug ineffective $\square$

A modern medicine $\square$, why : effective $\square$ accuracy $\square$

If both, what is the first one:

Modern medicine $\square$ Traditional medicine $\square$

\section{Plant material:}

Vernacular name:

Scientific name:

Part used : Stem $\square$ Flowers $\square$ Fruits $\square$ Seed $\square$

Bark $\square$ Rhizome $\square$ Bulb $\square$ Sheets $\square$

Whole plant $\square$ Other combinations $\square$ :

Form of use : herb tea $\square$ Powder $\square$ Essential Oils $\square$

Extract (tincture, solution, capsule) $\square$ :

Mode of preparation: Infusion $\square$ Decoction $\square$ Cataplasm $\square$ raw $\square$ Cooked $\square$

Others $\square$ :

Mode of administration :

Oral $\square$ Massage $\square$ Rinsing $\square$ Slathering $\square$ Others $\square$ :

Posology: number of catch per day :

For the children: Once/day $\square$ Twice/day $\square 3$ times/day $\square$ Others $\square$ :

For the elderly people: Once/day $\square$ Twice/day $\square 3$ times/day $\square$ Others $\square$ :

For the Adults: Once/day $\square$ Twice/day $\square 3$ times/day $\square$ Others $\square$ :

Duration of use (treatment duration):

Use:

One Day $\square$ One week $\square$ One month $\square$ Until healing $\square$

Type of disease:

Dermatological infections

Respiratory affections

Cardiovascular affections

Genito-urinary affections

Osteo-articular affections

Metabolic affections

Digestive affections

Digestive additional glands affections

Neurological affections 
Appendix 2. Catalog of medicinal plants used in the city of El-Jadida: list of plants identified by their Vernacular name and Scientific name, with classification by families.

\begin{tabular}{|c|c|c|}
\hline Family & Scientific Name & Vernacular name \\
\hline Amaranthaceae & Chenopodium ambrosioides & Mkhinza \\
\hline Amaryllidaceae & $\begin{array}{l}\text { Allium sativum } \\
\text { Allium cepa }\end{array}$ & $\begin{array}{l}\text { Touma } \\
\text { Basla }\end{array}$ \\
\hline Anacardiaceae & Pistacia lentiscus & Drou \\
\hline Apiaceae & $\begin{array}{l}\text { Petroselinum sativum } \\
\text { Cuminum cyminum } \\
\text { Ridolfia segetum } \\
\text { Coriandrum sativum } \\
\text { Ammi visnaga } \\
\text { Ammodaucus leucotrichus } \\
\text { Pimpinella anisum } \\
\text { Anethum graveolens } \\
\text { Foeniculum vulgare } \\
\end{array}$ & $\begin{array}{l}\text { Ma'dnous } \\
\text { Camon } \\
\text { Tabch } \\
\text { Qazbor } \\
\text { Bashnikha } \\
\text { Kamoun sofi } \\
\text { Habat hlawa } \\
\text { Karwiya } \\
\text { Nafae bsstani }\end{array}$ \\
\hline Asteraceae & $\begin{array}{l}\text { Chrysanthemum trifurcatum } \\
\text { Chamaemelum nobile } \\
\text { Atractylis gummifera } \\
\text { Artemisia herba-alba } \\
\text { Anacyclus pyrethrum }\end{array}$ & $\begin{array}{l}\text { L-gahwan romi } \\
\text { Babounj } \\
\text { Dad } \\
\text { Chih } \\
\text { Tiquanducht }\end{array}$ \\
\hline Brassicaseae & $\begin{array}{l}\text { Brassica rapa } \\
\text { Lepidium sativum }\end{array}$ & $\begin{array}{l}\text { Laft } \\
\text { Hab rchad }\end{array}$ \\
\hline Cactaceae & Opuntia ficus-indica & Drag \\
\hline Camelliaceae & Camellia thea & Atay \\
\hline Capparidaceae & Capparis spinosa & Kabar \\
\hline Caryophyllaceae & $\begin{array}{l}\text { Herniaria hirsuta } \\
\text { Corrigiola telephiifolia }\end{array}$ & $\begin{array}{l}\text { Harass lhjar } \\
\text { Sarghina }\end{array}$ \\
\hline Cucurbitaceae & $\begin{array}{l}\text { Citrullus colocynthis } \\
\text { Cucumis sativus }\end{array}$ & $\begin{array}{l}\text { Hadja } \\
\text { Khyar }\end{array}$ \\
\hline Cupressaceae & Juniperus phoenicea & Ar'ar \\
\hline Fabaceae & $\begin{array}{l}\text { Ceratonia siliqua } \\
\text { Cicer arietinum } \\
\text { Glycirrhiza glabra } \\
\text { Trigonella foenum -graecum }\end{array}$ & $\begin{array}{l}\text { Kharoub } \\
\text { Hamass } \\
\text { Arq-sous } \\
\text { Halba }\end{array}$ \\
\hline Fagaceae & Quercus rotundifolia & Dbag \\
\hline Jugclandaceae & Juglans regia & Swak \\
\hline Lamiaceae & $\begin{array}{l}\text { Ajuga iva } \\
\text { Thymus broussonetii } \\
\text { Salvia officinalis } \\
\text { Origanum majorana } \\
\text { Marrubium vulgare } \\
\text { Mentha pulegium } \\
\text { Rosmarinus officinalis } \\
\text { Satureja calamintha } \\
\text { Origanum compactum }\end{array}$ & $\begin{array}{l}\text { Chandgoura } \\
\text { Z'itra } \\
\text { Salmiya } \\
\text { Mardadouch } \\
\text { Mriwa } \\
\text { Flio } \\
\text { Yazir } \\
\text { Manta } \\
\text { Zaetar } \\
\end{array}$ \\
\hline Lauraceae & Cinnamomum zeylanicum & Qarfa \\
\hline Linaceae & Linum usitatissimum & Zeri't 1-kattan \\
\hline Lythraceae & Punica granatum & Romane \\
\hline Moraceae & Ficus carica & Nowart karmouss \\
\hline Musaceae & Musa paradisiaca & Banane \\
\hline Myristicaceae & Myristica fragrans & Gouza \\
\hline Myrtaceae & $\begin{array}{l}\text { Eucalyptus globulus } \\
\text { Eugenia caryophyllata } \\
\text { Myrtus communis }\end{array}$ & $\begin{array}{l}\text { Kalitus } \\
\text { Kranfal } \\
\text { Rihane } \\
\end{array}$ \\
\hline Oleaceae & Fraxinus dimorpha & lssan tire \\
\hline Palmaceae & Phoenis dactylifera & Tmar \\
\hline Poaceae & $\begin{array}{l}\text { Pennisetum typhoides } \\
\text { Triticum aestivum }\end{array}$ & $\begin{array}{l}\text { Ilane } \\
\text { Nakhala }\end{array}$ \\
\hline Piperaceae & Piper longum & Dar felfel \\
\hline Ranunculaceae & $\begin{array}{l}\text { Ranunculus muricatus } \\
\text { Nigella sativa }\end{array}$ & $\begin{array}{l}\text { Wedn halof } \\
\text { Sanouj }\end{array}$ \\
\hline Rhamnaceae & Ziziphus lotus & Nbag \\
\hline Rosaceae & Rosa damascena & Ward \\
\hline Rubiaceae & Rubia peregrina & Foua \\
\hline Rutaceae & Citrus limon & Hamad \\
\hline Schisandraceae & Illicium verum & Badiane \\
\hline
\end{tabular}

